\title{
Fruit sensory characterization of four Pescabivona, white-fleshed peach [Prunus persica (L.) Batsch], landraces and correlation with physical and chemical parameters
}

Giuseppe MoNTEVECCHI ${ }^{1 *}$, Giuseppe VASILE SIMONE ${ }^{2}$, Maria Gabriella MELLANO ${ }^{3,4}$, Francesca MASINO ${ }^{1,2}$, Andrea ANTONELLI $^{1,2}$

${ }^{1}$ Cent. Ric. Interdip.

Miglioramento Valoriz. Risorse Biol. Agro-Aliment. BIOGEST-SITEIA, Univ. Studi Modena Reggio Emilia, c/o Via G. Amendola 2 (Padiglione Besta), 42122 Reggio Emilia, Italy,

giuseppe.montevecchi@unimore.it

2 Dip. Sci. Vita

(Area Sci. Agro-Aliment.), Univ. Studi Modena Reggio Emilia, Via G. Amendola 2 (Padiglione Besta), 42122 Reggio Emilia, Italy

${ }^{3}$ Organ. Naz. Assaggiatori Frutta (O.N.A.Frut.), Piazza Foro Boario 18, 12100 Cuneo, Italy

${ }^{4}$ Dip. Colt. Arboree, Univ. Studi Torino, Via Leonardo da Vinci 44, 10095 Grugliasco (TO), Italy

* Correspondence and reprints

Received 7 May 2012 Accepted 17 July 2012

Fruits, 2013, vol. 68, p. 195-207 (c) 2013 Cirad/EDP Sciences All rights reserved DOI: $10.1051 /$ fruits/2013067 Www.fruits-journal.org

RESUMEN EsPañol, p. 207
Fruit sensory characterization of four Pescabivona, white-fleshed peach [Prunus persica (L.) Batsch], landraces and correlation with physical and chemical parameters.

Abstract - Introduction. Pescabivona is the name of an autochthonous peach [Prunus persica (L.) Batch] population of the central west of Sicily. In a previous work, this fruit was submitted to chemical analysis, while in this paper, sensory evaluation is considered. Materials and methods. Samples of four Pescabivona landraces were harvested throughout the harvest season. A trained panel outlined the sensory profiles and the data were processed by ANOVA and Principal Component Analysis (PCA). A correlation between sensory analysis and instrumental data was finally carried out. Results and discussion. The results demonstrated a high standard of quality for the four landraces studied, with some differences in aroma intensity and in some other parameters, with sweetness and aroma being highly correlated with overall liking. PCA did not clearly separate the different landraces as they have the same origin. Some correlations between sensory analysis and instrumental data were verified. The sensory liking was correlated with the main ripeness parameters, as well as with the pulp firmness. Conclusion. The data obtained contribute to outlining a complete fruit profile for product comparison and shelf-life monitoring. As previously verified for chemical parameters, the sensory evaluation indicates a substantial similarity among the landraces. The good agreement between sensory evaluation and composition makes sensory analysis a precious tool to assess quality of Pescabivona landraces.

Italy / Sicily / Prunus persica / land varieties / fruits / organoleptic properties / component analysis / regression analysis / quality / acceptability

Caractérisation sensorielle des fruits de quatre variétés de Pescabivona, pêches à chair blanche [Prunus persica (L.) Batsch], et corrélation avec certains paramètres physiques et chimiques.

Résumé - Introduction. Pescabivona est le nom d'une population de pêchers autochtones [Prunus persica (L.) Batsch] de l'ouest de la Sicile. Dans un travail précédent, nous avions effectué des analyses chimiques de ce fruit, tandis que, dans le document présent, nous avons fait l'évaluation sensorielle du produit. Matériel et méthodes. Des échantillons de quatre variétés locales de Pescabivona ont été récoltés durant toute la saison de la récolte. Un panel expérimenté a évalué les profils sensoriels des fruits échantillonnés et les données ont été traitées par analyse de variance et analyse en composantes principales (ACP). Une corrélation entre l'analyse sensorielle et les données chimiques a finalement été mesurée. Résultats et discussion. Les résultats ont démontré une très bonne qualité pour les fruits des quatre variétés étudiées, avec quelques différences d'intensité aromatique et de certains autres paramètres, la douceur et l'arôme étant fortement corrélés avec le goût en général. L'ACP n'a pas permis de séparer clairement les différentes variétés locales car elles ont la même origine. Les corrélations entre l'analyse sensorielle et les données de composition chimique ont été vérifiées. Le goût a été corrélé aux principaux paramètres de maturité, ainsi qu'à la fermeté de la pulpe. Conclusion. Les données obtenues contribuent à définir un profil sensoriel complet des fruits pour leur comparaison et le contrôle de leur durée de vie. Comme pour les paramètres chimiques vérifiés précédemment, l'évaluation sensorielle a révélé une importante similarité des variétés locales. La concordance entre l'évaluation sensorielle et la composition des fruits fait de l'analyse sensorielle un outil précieux pour l'évaluation de la qualité des variétés locales de pêches Pescabivona.

Italie / Sicile / Prunus persica / variété indigène / fruits / propriété organoleptique / analyse en composantes / analyse de régression / qualité / acceptabilité 


\section{Introduction}

Peach and nectarine fruit [Prunus persica (L.) Batch] are the second most important fruit crops in the European Union (EU) after apple [1]

Sensory quality attributes of fruits play a crucial role in consumer satisfaction $[2,3]$ as well as in the approval of agricultural and food-chain subjects [4]. Although the quality of peaches can be successfully determined by physical and chemical analysis, sensory analysis is another useful approach to the evaluation of the fruit quality [3, 5-7]. In fact, if compared with physical and chemical analysis, sensory analysis has the remarkable advantage of selecting the attributes most affecting the consumer satisfaction [8]. These kinds of protocols are also progressively more used in breeding, in testing new cultivars (cvs.), and in storage practices [9].

In making decisions, consumers are primarily influenced by the appearance of peach (visible quality) [10]. However, other sensory parameters are involved in the preference of consumers. These parameters are often scarcely present in the peaches currently available on the market $[2,8]$. Among these parameters, peach flavor results from a delicate balance of sweetness, sourness, aroma and astringency, apart from additional physical attributes such as pulp texture. Taste is related to water-soluble compounds, while smell is elicited by volatile compounds. A balanced degree of sweetness and sourness is considered as a consistent characteristic with a positive correlation with consumers' preference $[2,3,8]$

Astringency is generally considered as a negative sensory trait, indicating unripe fruits $[11,12]$.

The relationships between the sensory and physical and chemical attributes of peach fruit are still a matter of investigation. An earlier study showed that the sensory evaluation of peaches did not match with main quality chemical factors well, not allowing a classification into groups [13]. However, the difficulty in correlating analytical and sensory measurements is well known, and it is attributed to the high variability of fruits [14].
More recently, Esti et al. proposed that the chemical characteristics of fruits could be used as effective comparative indicators of sensory quality [7]. In particular, the relationships between sugars, non-volatile acid content and some sensory attributes (sweetness and sourness) were studied in different peach and nectarine cvs.

On the contrary, Colaric et al. showed that titratable acidity (TA) and soluble solid content (SSC) could not be substituted for sensory evaluation of perceived sweetness and sourness due to the complexity of the latter attributes [6]. They demonstrated that the sugar/organic acid ratio and levels of organic acids have a significant impact on perception of sweetness. Moreover, these authors asserted that aroma could be influenced by fixed compounds, as well. Total organic acids, sucrose, sorbitol and malic acid influenced smell perception, while malic/citric acid ratio, total sugars, sucrose, sorbitol and malic acid affected the taste.

Different authors assert that an individual sensory attribute is better defined by a set of different molecules, which are involved in different measure in the attribute perception, rather than a single class of substance such as sugars for sweetness and organic acids for sourness [15].

In Sicily, as well as in other territories, environmental and human selection yields an interesting germplasm of Prunuspersica (L.) Batsch [16, 17]. Among this germoplasm, Pescabivona, also known as "Pesca di Bivona" [18], is the collective name of autochthonous landraces characteristic of the countryside around Bivona, in the central west of Sicily [19]. Nowadays, Pescabivona identifies four landraces called Murtiddara (also called Primizia Bianca), Bianca, Agostina and Settembrina [20]. They are characterized by different ripening times from the end of June (Murtiddara) up to the end of September (Settembrina).

These landraces were recently characterized by their physical and chemical profile composition [21], showing a general homogeneity of composition and giving evidence of quality in terms of high pulp firmness, sugar and lactone content, along with a balanced SSC/TA ratio. However, no study on 
sensory evaluation of Pescabivona has been reported. For this reason, the sensory traits of the four Pescabivona landraces were investigated.

This research was aimed at: i) gaining information on Pescabivona sensory characteristics by a trained panel of judges, and ii) establishing correlations between sensory analysis and physical and chemical data. The results can also contribute to providing a complete fruit profile for product comparison and shelf-life monitoring, to give support to growing activities based on local germplasm as a source of valuable quality features, to support the achievement of Protected Geographical Indication (PGI) according to the EU rules, and to provide information for marketing activity of the product, in terms of immediate information for the consumers.

\section{Materials and methods}

\subsection{Sampling}

Samples of the four Pescabivona peach landraces (Murtiddara, Bianca, Agostina and Settembrina) were collected inside the growing area around Bivona (Sicily, Italy, lat. $37^{\circ} 37^{\prime} 13^{\prime \prime} \mathrm{N}$, long. $13^{\circ} 26^{\prime} 26^{\prime \prime} \mathrm{E}$, alt. $500 \mathrm{~m}$ a.s.1.) throughout the harvest season.

Details on the characteristics of the orchards and the description of agronomic and growing techniques have already been reported [21].

The peaches were collected at the ripening stage "ready-to-eat". Fruits were evaluated by means of change in ground color from green to yellow and fruit size corresponding to AA caliber (diameter from $73 \mathrm{~mm}$ to $80 \mathrm{~mm}$, and circumference from $23 \mathrm{~cm}$ to $25 \mathrm{~cm}$ ). Since peach quality shows variability within trees [22], fruit sampling was standardized under the following conditions: medium vigor trees, rootstock GF 677 south exposure, external part of the tree.

A gross sample of 40 peaches was handpicked for each landrace from different trees. The samples were carefully put in refrigerated polystyrene boxes and they were immediately airmailed to the laboratory for sensory analysis. At the same time, a gross sample of 54 peaches was collected for each landrace, destined for physical and chemical analysis only [21].

Panel sessions were performed the day after each harvest. A few minutes before the session, once the room temperature was reached, the peeled samples were cut into pieces and gently mixed to reduce the variability.

\subsection{Sensory analysis}

\subsubsection{Panel of judges}

The panel of judges, recruited by the Organizzazione Nazionale Assaggiatori di Frutta (O.N.A.Frut.), comprised twelve subjects. All the judges had successfully attended a training course and they had performed sensory analysis for several years. The training activities include weekly sessions to improve perception sensitivity and evaluation of individual descriptors, in addition to evaluation of different fruit varieties.

These subjects, including males and females, aged from 20 to 60 years, were selected on the basis of the general guidance [23].

Their experience was considered suitable with regard to the senses of taste, smell and sight, and for general rules of sensory analysis, as reported in the standard methods $[23,24]$.

\subsubsection{Sensory evaluation of sliced fruits}

A descriptive analysis [25] was carried out by the trained panel group in individual sensory booths, to avoid exchange of opinions or any other conditioning. Each panelist was asked to evaluate visual, olfactive and gustative attributes by recording the intensity on a $10-\mathrm{cm}$ structured line scale anchored at each end [25, 26]. Eleven sensory attributes related to color, texture, odor, (retronasal) aroma, and taste of the analyzed samples were evaluated: pulp ground color, presence of red veins, fibrousness, hardness, juiciness, intensity of smell, sweetness, sourness, bitterness and aroma. Pulp ground 
color and presence of red veins were visually evaluated. Finally, each panelist was asked to express the overall liking to provide the potential consumer acceptance.

\subsubsection{Sensory evaluation of entire fruits}

In order to prevent the possible influence of fruit appearance on sensory evaluation, the descriptive evaluation of the whole fruit was carried out at the end of each panel session. Judges were asked to evaluate the geometric shape, symmetry of shape, peel ground color, percentage and kind of peel blush color, and intensity of smell.

\subsection{Physical and chemical analysis}

Physical and chemical profiling of the samples was described in a previous paper [21] Here, a list of the determinations is simply reported:

a) color and color distance analysis for pee and pulp color were determined as CIE coordinates $\left(L^{*}, a^{*}\right.$, and $\left.b^{*}\right)$ [27] by a reflectance chromameter:

b) physical and chemical analysis such as weight, pulp firmness, $\mathrm{pH}$, soluble solid content (SSC) and titratable acidity (TA) were determined by electronic balance, fruit pressure tester, refractometer, $\mathrm{pH}$-meter and titration, respectively; the SSC/TA ratio was also calculated;

c) organic acids and sugars were determined by HPLC after extraction;

d) flavan-3-ols and hydroxycinnamic acids were determined on peel and pulp by UV/ Vis spectrophotometer after extraction;

e) antioxidant capacity was determined on peel and pulp by 2,2'-azino-bis(3-ethylbenzothiazoline-6-sulphonic acid) (ABTS) radical cation decolorization assay after extraction;

f) lactones were determined by GC after extraction and concentration.

\subsection{Statistical analysis}

Analysis of variance (ANOVA), Tukey's multiple comparison test [28], linear regression analysis and principal component analysis (PCA) were performed using Statistica version 8.0 software (Stat Soft Inc., Tulsa, USA).

\section{Results and discussion}

\subsection{Sensory analysis of sliced fruits and one-way ANOVA}

Among the texture descriptors, fibrousness and juiciness showed statistically significant differences $(p \leq 0.01)$, while hardness did not, although Settembrina had a hardness mean value slightly higher than that of the other landraces (table I).

Fibrousness had the highest scores for Agostina and intermediate scores for Bianca and Settembrina, whereas Murtiddara showed the lowest values. Probably for this reason, Murtiddara was the landrace with the highest juiciness scores, followed by Bianca and Agostina, while Settembrina was judged as the least juicy.

All the landraces were described as very fragrant, and ANOVA did not show any statistical difference.

Taste descriptors, conversely, allowed a more remarkable discrimination among the landraces. Settembrina was the sweetest peach $(p \leq 0.05)$, whereas the lowest scores were recorded for Murtiddara. Consistently, Murtiddara came out as the sourest peach $(p \leq 0.01)$, followed by Bianca and Settembrina, while Agostina was by far the least. Finally, bitterness highlighted the differences $(p \leq 0.001)$ among the landraces. Bianca was judged as the bitterest peach (2.63), while Murtiddara and Agostina reached remarkably lower scores $(0.50$ and 0.71). Also, aroma (retronasal perception) showed some differences among the landraces. The most aromatic landrace was Settembrina, followed by Agostina and Murtiddara, while Bianca came last.

All samples were described as white-pulp peaches, while the presence of red veins near the stone was registered for all the landraces, except Murtiddara. Moreover, the sample of this landrace showed a large variability. In fact, $73 \%$ of the fruits did not 


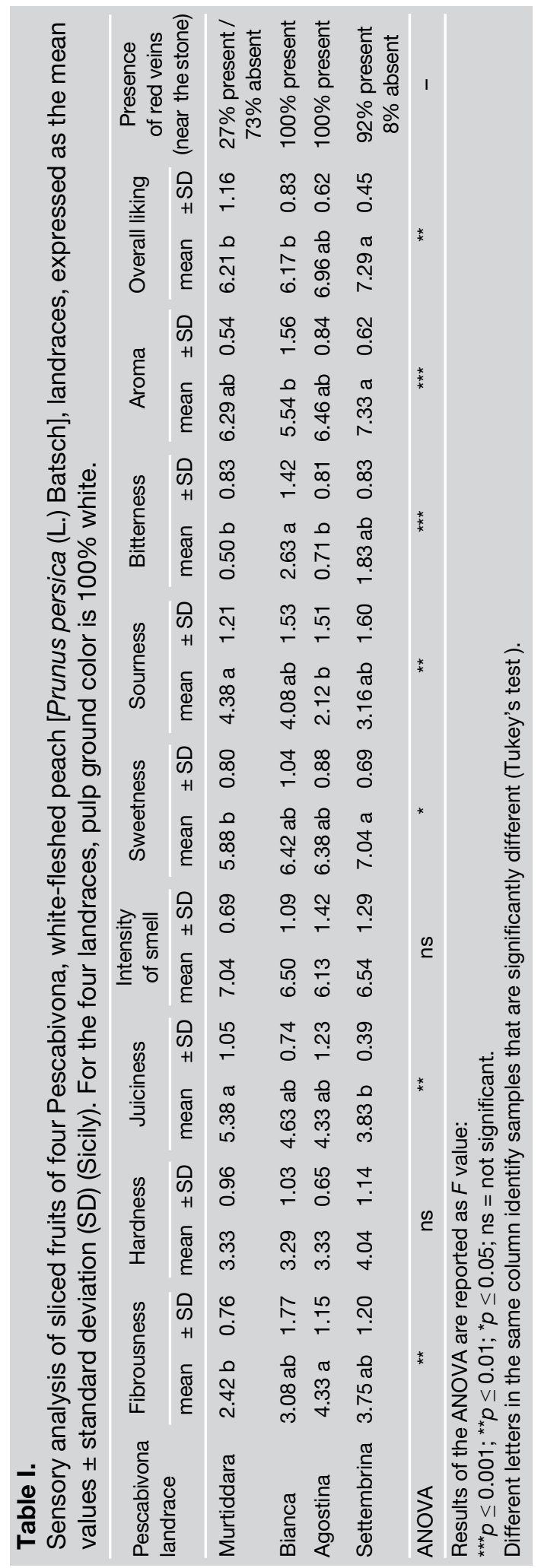




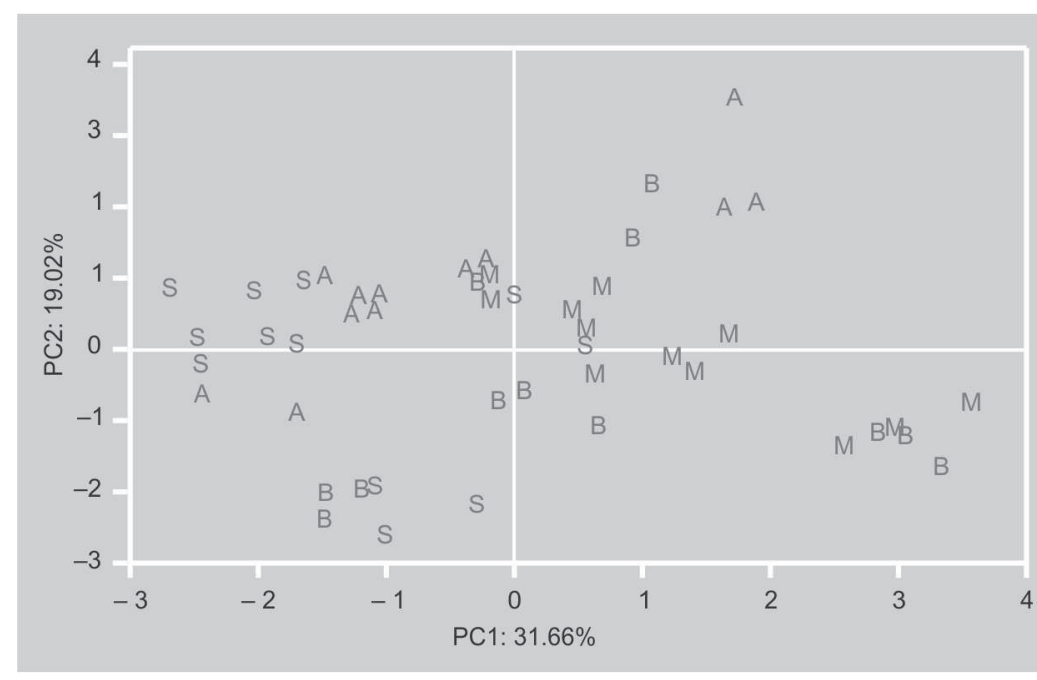

Figure 1.

Study of sensory characters for replicated fruit samples of four Pescabivona landraces [Prunus persica (L.) Batsch] (M, Murtiddara; B, Bianca; A, Agostina; S, Settembrina): the first two principal components (PC1 vs. PC2) with the explained variances of a principal component analysis. show any veins, 18\% showed red veins near the stone, and 9\% showed widespread red veins in the pulp.

\subsection{Sensory analysis of whole fruits}

Geometrical shape was described as spheroidal for all landraces except for Bianca, that was described as oblate-spheroidal. Only Murtiddara was described as without shape symmetry.

Peel ground color was yellow-green for Murtiddara and Bianca, white-green for Agostina, and white for Settembrina, while peel blush color was red for all the landraces.

All the whole unpeeled peaches were described as markedly fragrant. Murtiddara and Bianca were described as highly fragrant, while Agostina scored $42 \%$ of high cases, $33 \%$ of medium ones, and $25 \%$ of low ones. Finally, Settembrina was considered for $58 \%$ as high cases and $42 \%$ as medium ones.

\subsection{Principal component analysis}

Principal component analysis (PCA) was applied to the autoscaled data to detect the most important variables for determining their structure. The first three principal components (PCs) showed eigenvalues $>1.0$ [29] explaining $65.8 \%$ of the total variance.

The plot of the PC1 $(31.66 \%$ of total variability) vs. PC2 (19.02\% of total variability) showed that the samples of the different landraces did not clearly separate into different clusters (figure 1). This means that there is not a clear segregation of the landraces according to their organoleptic characteristics, as proposed by Crisosto et al. [15] for peach and nectarine crs., thus confirming the general homogeneity of the Pescabivona landraces. In more detail, samples are scattered on the plane, with a tendency for clustering for some landraces. For example, Settembrina is grouped on PC1, while Murtiddara makes a loose cluster on PC2. This behavior confirms a close relation among the different landraces, and the fact that they have the same geographical origin. In other terms, the differences are more apparent than real. On the other hand, similar considerations were also achieved for physical and chemical determinations [21].

Murtiddara (M) had almost always positive values on PC1 due to its high juiciness and low fibrousness. On the contrary, Agostina (A) and, much more, Settembrina (S) showed negative values on PC1 due to low juiciness and high fibrousness, but also aroma and overall liking. However, three samples of Agostina were characterized by positive values on PC1 and PC2 and three samples of Settembrina by negative values on PC1 and PC2, probably due to high juiciness and low fibrousness along with low intensity of smell and sweetness for the Agostina samples and to high hardness, sourness and bitterness for the Settembrina samples.

It is interesting to note that fibrousness and juiciness texture descriptors had high weights on PC1 (figure 2), with opposite signs, the former negative and the latter positive, while hardness was orthogonal to both.

PC3 (15.12\% of total variability) did not show any loading value $>0.5$. The scores (figure 3) confirmed the scatter of the Bianca samples, but also Murtiddara, along this axis, while Agostina and Settembrina were located in a more limited area. 


\subsection{Correlation among the sensory descriptors}

As observed for PCA and as expected, fibrousness and juiciness were negatively correlated $(p \leq 0.001$ ) (table II $)$ ). The texture descriptors did not evidence any other correlation. It was noteworthy that the overall liking was highly correlated not only with sweetness $(|\mathrm{r}|=0.48 ; p \leq 0.001)$, but also and much more with aroma $(|\mathrm{r}|=0.68$; $p \leq 0.001$ ).

Likewise, sweetness and aroma showed a high linear correlation $(|\mathrm{r}|=0.44$; $\mathrm{p} \leq 0.01$ ) (table IIb). A similar result has already been observed [30, 31], while Infante et al. [32] found a high correlation between sweetness and aroma for preconditioned peach assessment on fruit maintained in cold storage. However, this correlation did not match with acceptability. Moreover, sweetness also had a high positive correlation with fibrousness, intensity of smell, bitterness, and a negative correlation with juiciness. Aroma was also negatively correlated with juiciness, which is considered a negative attribute for panel liking.

Sourness was correlated only with texture attributes, positively with hardness and juiciness, and negatively with fibrousness (table IIc).

\subsection{Relationships between the sensory and physical and chemical attributes}

The relationships between sensory and physical and chemical attributes were studied by linear regression analysis. In order to have a simpler correlation matrix, only sensory data were correlated with physical and chemical data [21] and with some indices: the $\left[a^{*} / b^{*}\right]$ ratio [1], [sucrose/(glucose + fructose)], [malic acid/citric acid] and [total sugars/total organic acids] [6] (table III).

Fibrousness is positively correlated with background skin color $a^{*}$, background skin $\left[a^{*} / b^{*}\right]$, weight, pulp $\mathrm{pH}$, [SSC/TA], [malic $\mathrm{acid} /$ citric acid], quinic acid and [total sugars/total organic acids]. These data confirmed the positive correlation between

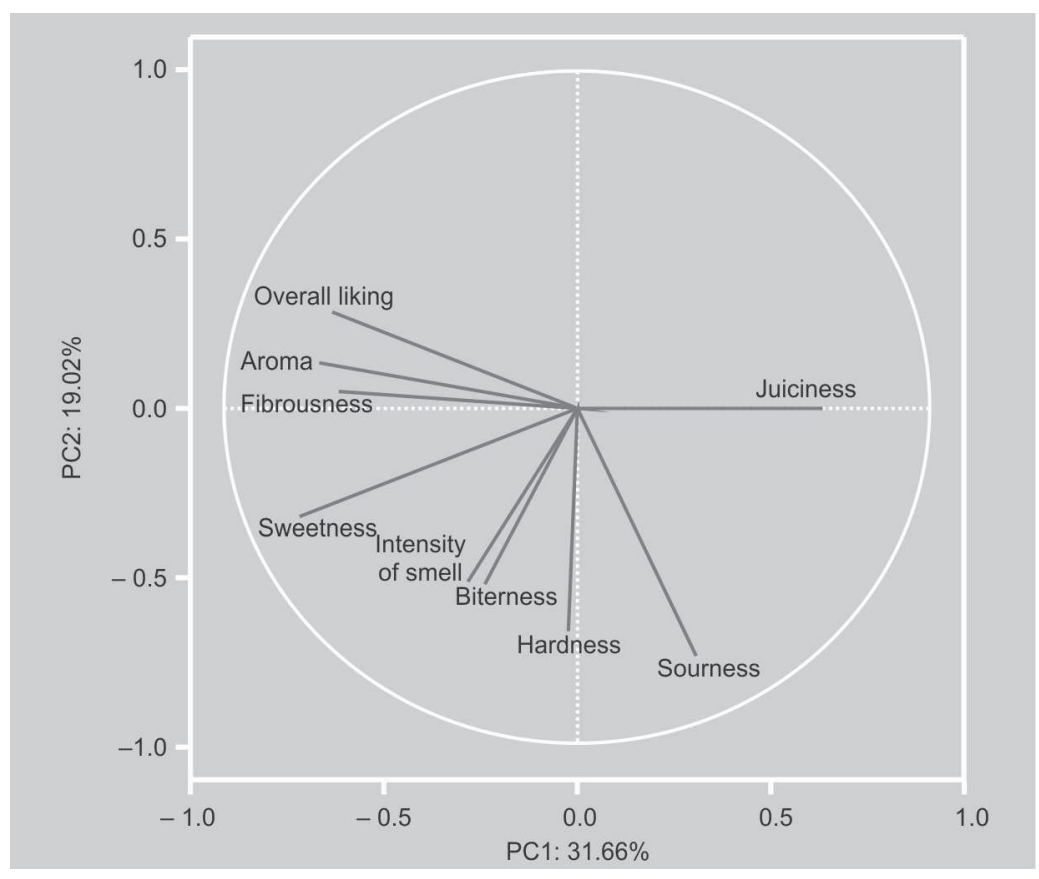

fibrousness and sweetness, as well as the negative correlation between fibrousness and sourness.

As expected, hardness is positively correlated with pulp firmness, but also with malic acid, sucrose and [sucrose/(glucose + fructose)], as a consequence of the fact that hardness is a ripeness attribute.

The third texture attribute, juiciness, is mainly correlated with the same parameters listed for hardness but with opposite signs.

Intensity of smell, unexpectedly, showed negative correlations with the main volatiles, expressed as odor activity values (OAVs), as well as the total lactone OAV. This behavior is hard to explain, even if it is well known that odor intensity and concentration are not always positively correlated (saturation). In addition, intensity of smell did not show any statistical difference among the four landraces. Moreover, this parameter is highly correlated with all the acidity parameters and with background skin color $a^{*}$, indicating a positive relationship between unripeness and smell. However, this anomalous behavior has already been reported by Peano et al. [4] and ascribed to the panel.
Figure 2.

Study of sensory characters for replicated fruit samples of Pescabivona landraces [Prunus persica (L.) Batsch]: plot of the loading values of sensory attributes on the first and second components (PC1 vs. PC2) with the explained variances. 


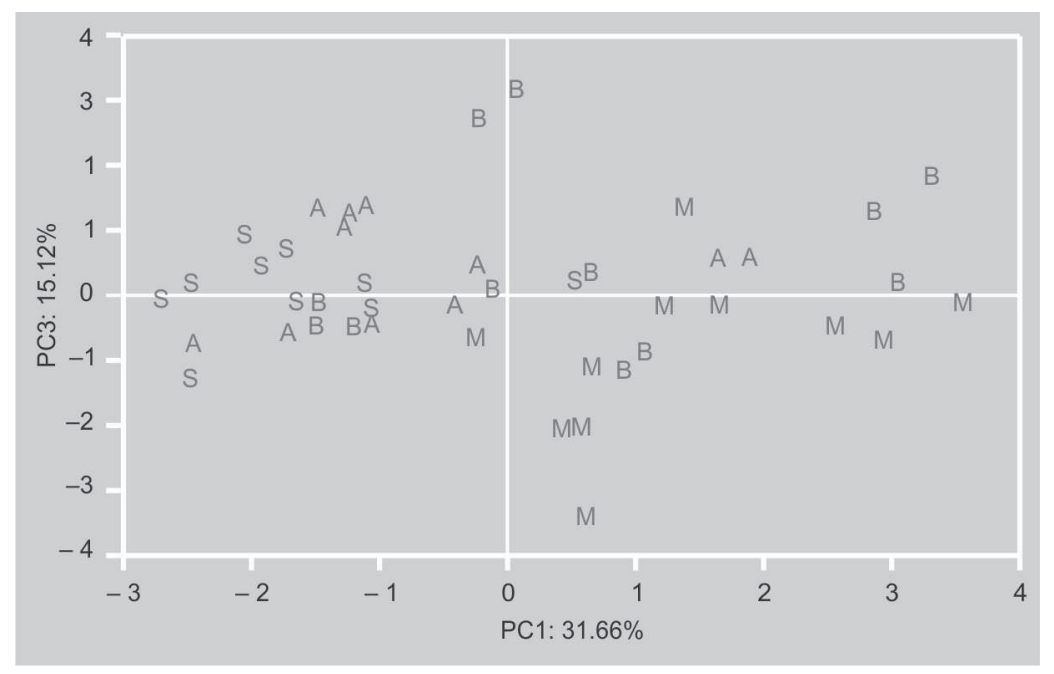

Figure 3.

Study of sensory characters for replicated fruit samples of four Pescabivona landraces [Prunus persica (L.) Batsch] (M, Murtiddara; B, Bianca; A, Agostina; S, Settembrina): the first and third principal components (PC1 vs. PC3) with the explained variances of a principal component analysis.
Sweetness is highly correlated with SST, sucrose, total sugars, total sugar content corrected with the relative sweetness for each carbohydrate [33], [sucrose/(glucose + fructose)], malic acid, and pulp color $\left[a^{*} / b^{*}\right.$, showing that the panel attributed the highest scores to the fruits with the highest sugar content and ripeness. A positive correlation was also recorded between sweetness and phenolics.

Sourness is negatively correlated with pulp $\mathrm{pH}$, [SSC/TA], [malic acid/citric acid] and [total sugars/total organic acids], while it is positively correlated with titratable acidity, citric acid and pulp hydroxycinnamic acids. These results indicated that this attribute was evaluated in an unequivocal way by the panel.

An interesting positive high correlation is shown between bitterness, phenolics and lactone OAVs. Flavan-3-ols are responsible for bitterness and astringency [34], and hydroxycinnamic acids show a bitter-sour taste [35]. Lactones are also described as bitter substances. The bitter thresholds for $\gamma$ - and $\delta$-decalactone are 340 and $420 \mu \mathrm{mol} \cdot \mathrm{L}^{-1}$, respectively. Independently of the $\gamma$ - or $\delta$-lactone ring, the threshold for bitterness increases with an elongation of the aliphatic chain [36].

Overall liking is correlated with the main ripeness parameters, positively with background skin $\left[a^{*} / b^{*}\right]$, weight, [malic acid/citric acid], and [sucrose/(fructose + glucose)], and negatively with citric acid and fructose. Overall liking, as well as aroma, is positively correlated with pulp firmness, once again confirming the assumption that the firmness of the fruit at the ripe stage is not only suitable for transport, but also associated with the sugar and acid content typical of freshmarket quality peaches.

\section{Table II.}

Significant correlation matrix of the sensory analysis data set resulting from the fruit studies of four Pescabivona, white-fleshed peach [Prunus persica (L.) Batsch], landraces.

a) $p \leq 0.001$

\begin{tabular}{lccc}
\hline Characters & Fibrousness & Sweetness & Aroma \\
Juiciness & -0.54 & & \\
Overall liking & & 0.48 & 0.68
\end{tabular}

b) $p \leq 0.01$

$\begin{array}{lcccc}\text { Characters } & \text { Fibrousness } & \text { Juiciness } & \text { Intensity of smell } & \text { Sweetness } \\ \text { Sweetness } & 0.45 & -0.41 & 0.37 & 0.37 \\ \text { Bitterness } & & & 0.44 \\ \text { Aroma } & & & \\ \text { c) } p \leq 0.05 & & & \\ \text { Characters } & \text { Fibrousness } & \text { Hardness } & \text { Juiciness } \\ \text { Sourness } & -0.35 & 0.32 & 0.36 \\ \text { Aroma } & & & -0.30\end{array}$




\begin{tabular}{|c|c|c|c|c|c|c|c|c|c|}
\hline \multicolumn{10}{|l|}{ a) $p \leq 0.001$} \\
\hline $\begin{array}{l}\text { Chemical and physical } \\
\text { parameters }\end{array}$ & Fibrousness & Hardness & Juiciness & $\begin{array}{l}\text { Intensity } \\
\text { of smell }\end{array}$ & Sweetness & Sourness & Bitterness & Aroma & $\begin{array}{l}\text { Overall } \\
\text { liking }\end{array}$ \\
\hline Background skin color $a^{*}$ & 0.839 & & & -0.852 & & & & & \\
\hline Background skin $\left[a^{\star} / b^{\star}\right]$ & 0.861 & & & -0.863 & & & & & \\
\hline Pulp color $L^{*}$ & & -0.836 & & & -0.870 & & & & \\
\hline Weight & & & -0.930 & & 0.883 & & & & \\
\hline \multicolumn{10}{|l|}{ Pulp firmness } \\
\hline Pulp pH & & & & -0.883 & & & & & \\
\hline Soluble solid content & & & & & 0.874 & & 0.853 & & \\
\hline $\begin{array}{l}\text { [Soluble solid content } \\
\text { / titratable acidity] }\end{array}$ & 0.904 & & & -0.938 & & -0.903 & & & \\
\hline Citric acid & -0.965 & & & 0.968 & & 0.914 & & & \\
\hline Malic acid & & 0.850 & & & 0.874 & & & & \\
\hline Quinic acid & 0.827 & & & -0.864 & & -0.889 & & & \\
\hline [Malic acid / citric acid] & 0.926 & & -0.851 & -0.848 & & -0.866 & & & \\
\hline Fructose & & -0.950 & 0.862 & & -0.919 & & & -0.831 & -0.867 \\
\hline Sucrose & & & & & 0.858 & & & & \\
\hline $\begin{array}{l}\text { [Sucrose / } \\
\text { (fructose + glucose)] }\end{array}$ & & 0.961 & & & 0.893 & & & & \\
\hline $\begin{array}{l}\text { [Total sugars / } \\
\text { total organic acids] }\end{array}$ & & & & -0.851 & & & & & \\
\hline Pulp total phenolics & & & & & & & 0.850 & & \\
\hline Pulp antioxidant capacity & & & & & & & 0.849 & & \\
\hline $\begin{array}{l}\mathrm{C}_{10} \delta \text {-lactone odor activity } \\
\text { value }\end{array}$ & & & & & & & 0.907 & & \\
\hline \multicolumn{10}{|l|}{ b) $p \leq 0.01$} \\
\hline Background skin color $L^{*}$ & & & & & & & 0.777 & & \\
\hline Background skin color $a^{\star}$ & & & & & & -0.810 & & & \\
\hline Background skin $\left[a^{*} / b^{*}\right]$ & & & & & & -0.822 & & & \\
\hline Skin blush color $b^{\star}$ & & & & 0.718 & & & & & \\
\hline Pulp color $L^{*}$ & & & 0.732 & & & & & & \\
\hline Pulp color $\left[a^{*} / b^{\star}\right]$ & & & -0.726 & & 0.771 & & & & \\
\hline Weight & 0.759 & & & & & & & & 0.759 \\
\hline Pulp firmness & & 0.782 & & & & & & 0.752 & \\
\hline Pulp pH & 0.794 & & & & & -0.726 & & & \\
\hline Soluble solid content & & & -0.806 & & & & & & \\
\hline Titratable acidity & & & & 0.730 & & 0.783 & & & \\
\hline Citric acid & & & 0.765 & & & & & & \\
\hline Malic acid & & & -0.710 & & & & & & \\
\hline Succinic acid & & & & & & -0.712 & & & \\
\hline [Malic acid / citric acid] & & & & & & & & & 0.810 \\
\hline
\end{tabular}


Table III. Continued.

b) $p \leq 0.01$

\begin{tabular}{|c|c|c|c|c|c|c|c|c|c|}
\hline $\begin{array}{l}\text { Chemical and physical } \\
\text { parameters }\end{array}$ & Fibrousness & Hardness & Juiciness & $\begin{array}{l}\text { Intensity } \\
\text { of smell }\end{array}$ & Sweetness & Sourness & Bitterness & Aroma & $\begin{array}{l}\text { Overall } \\
\text { liking }\end{array}$ \\
\hline Glucose & & & & & & & 0.771 & -0.752 & \\
\hline Sucrose & & 0.788 & -0.712 & & & & & & \\
\hline Total sugars & & & & & 0.782 & & 0.778 & & \\
\hline Total sugar content corrected & & & & & 0.736 & & 0.786 & & \\
\hline [Sucrose / (fructose + glucose)] & & & -0.779 & & & & & 0.767 & 0.742 \\
\hline [Total sugars / total organic acids] & 0.749 & & & & & -0.716 & & & \\
\hline Pulp flavan-3-ols & & & & & 0.747 & & 0.816 & & \\
\hline $\mathrm{C}_{10} \gamma$-lactone odor activity value & & & & & & & 0.773 & & \\
\hline $\mathrm{C}_{12} \gamma$-lactone odor activity value & & & & -0.801 & & & & & \\
\hline Total lactone odor activity value & & & & -0.754 & & & & & \\
\hline \multicolumn{10}{|l|}{ c) $p \leq 0.05$} \\
\hline Background skin color $L^{*}$ & & & -0.555 & & 0.690 & & & & \\
\hline Background skin color $a^{*}$ & & & -0.617 & & & & & & \\
\hline Background skin $\left[a^{\star} / b^{\star}\right]$ & & & -0.669 & & & & & & 0.597 \\
\hline Skin blush color $L^{*}$ & -0.691 & & 0.672 & 0.578 & & 0.657 & & & -0.702 \\
\hline Skin blush color $a^{*}$ & & & & & & & 0.593 & & \\
\hline Pulp color $L^{*}$ & & & & & & & -0.604 & & \\
\hline Pulp color $a^{*}$ & & & & & 0.654 & & 0.595 & & \\
\hline Pulp color $b^{*}$ & & & & -0.587 & & & & & \\
\hline Pulp color $\left[a^{*} / b^{\star}\right]$ & & & & & & & 0.648 & & \\
\hline Percentage of skin blush color & & & & 0.640 & & & -0.585 & & \\
\hline Weight & & 0.618 & & -0.686 & & -0.619 & & & \\
\hline Pulp firmness & & & & & & & & & 0.608 \\
\hline Pulp pH & & & -0.596 & & & & & & \\
\hline Titratable acidity & -0.697 & & & & & & & & \\
\hline Citric acid & & & & & & & & & -0.672 \\
\hline Malic acid & & & & & & & 0.668 & & \\
\hline Succinic acid & 0.581 & & & & & & -0.582 & & \\
\hline Total organic acids & & 0.671 & & & & & & & \\
\hline [Malic acid / citric acid] & & & & & 0.700 & & & & \\
\hline Sucrose & & & & & & & 0.685 & & \\
\hline Total sugars & & 0.665 & -0.626 & & & & & & \\
\hline Total sugar content corrected & & 0.616 & -0.576 & & & & & & \\
\hline Pulp flavan-3-ols & & & -0.700 & & & & & & \\
\hline Pulp hydroxycinnamic acids & & & & & & 0.647 & 0.691 & -0.652 & -0.634 \\
\hline Pulp total phenolics & & & -0.612 & & 0.676 & & & & \\
\hline $\mathrm{C}_{10} \gamma$-lactone odor activity value & & & & -0.682 & & & & & \\
\hline $\mathrm{C}_{12} \gamma$-lactone odor activity value & 0.595 & & & & & & 0.601 & & \\
\hline Total lactone odor activity value & & & & & & & 0.681 & & \\
\hline
\end{tabular}




\section{Conclusion}

Our paper reported the first detailed study on sensory profiles of the four landraces of Pescabivona obtained by a trained panel of judges. The data obtained contributes to outlining a complete fruit profile for product comparison and shelf-life monitoring.

Many analytical parameters are correlated with the sensory attributes, and for this reason sensory evaluation is a precious tool for assessing quality of Pescabivona.

Finally, the results obtained so far support the study of local germplasm as a source of valuable quality features, with a positive effect on the local economy and agroecosystem.

\section{Acknowledgments}

We wish to acknowledge the "Comune di Bivona" (Italy) for having funded this research. The authors are grateful to $\mathrm{Mr}$. Carmelo Vasile Simone and the other farmers for their cooperation in supplying the samples.

\section{References}

[1] Iglesias I., Echeverría G., Differential effect of cultivar and harvest date on nectarine colour, quality and consumer acceptance, Sci. Hortic. (Amst.) 120 (2009) 41-50.

[2] Infante R., Martínez-Gómez P., Predieri S., Quality oriented fruit breeding: Peach [Prunus persica (L.) Batsch], J. Food Agric. Environ. 6 (2) (2008) 342-356.

[3] Predieri S., Ragazzini P., Rondelli R., Sensory evaluation and peach fruit quality, Acta Hortic. 713 (2006) 429-434.

[4] Peano C., Chiabrando V., Giacalone G. Astesano B., Sensory and instrumental evaluation of peach and nectarine varieties [Prunus persica (L.) Batsch; Piedmont], Ind. Aliment. (Italy) 43 (2004) 863-867.

[5] Brovelli E.A., Brecht J.K., Sherman W.B., Sims C.A., Harrison J.M., Sensory and compositional attributes of melting- and non-melting-flesh peaches for the fresh market, J. Sci. Food Agr. 79 (1999) 707-712.
[6] Colaric M., Veberic R., Stampar F., Hudina $M$. Evaluation of peach and nectarine fruit quality and correlations between sensory and chemical attributes, J. Sci. Food Agric. 85 (2005) 2611-2616.

[7] Esti M., Messia M.C., Sinesio F., Nicotra A., Conte L., La Notte E., Palleschi G., Quality evaluation of peaches and nectarines by electrochemical and multivariate analyses: relationships between analytical measurements and sensory attributes, Food Chem. 60 (1997) 659-666.

[8] Castellari L., I caratteri della qualità. Pianeta pesca. Qualità e sicurezza per il consumatore, II Divulgatore 3-4 (2002).

[9] Infante R., Meneses C., Byrne D., Present situation of peach breeding programs: post harvest and fruit quality assessment, Acta Hortic. 713 (2006) 121-124.

[10] Kays S.J., Preharvest factors affecting appearance, Postharvest Biol. Technol. 15 (1999) 233-247.

[11] Ozawa T., Lilley T.H., Haslam E., Polyphenol interactions: astringency and the loss of astringency in ripening fruit, Phytochemistry 26 (1987) 2937-2942.

[12] Robertson J.A., Meredith F.I., Scorza R., Physical, chemical and sensory evaluation of high and low quality peaches, Acta Hortic. 254 (1989) 155-160.

[13] Bassi D., Selli R., Evaluation of fruit quality in peach and apricot, Adv. Hortic. Sci. 4 (1990) 107-112.

[14] Bourne M.C., Rupture tests vs. small-strain in predicting consumer response to texture, Food Technol. (Chic.) 10 (1979) 67-70.

[15] Crisosto C.H., Crisosto G.M., Echeverria G., Puy J., Segregation of peach and nectarine [Prunus persica (L.) Batsch] cultivars according to their organoleptic characteristics, Postharvest Biol. Technol. 39 (2006) 10-18.

[16] Caruso T., Di Lorenzo R., Barone E., II germoplasma del pesco in Sicilia: Aspetti genetici e bioagronomici, in: Agabbio $M$. (Ed.), Proc. IV Natl. Congr. "Germoplasma frutticolo salvaguardia e valorizzazione delle risorse genetiche", Alghero, Italy, 1992, pp. 285-293.

[17] Marchese A., Tobutt K., Campisi G., Cartabellotta D., Di Martino V., Marrone G., Caruso T., II germoplasma autoctono del pesco [Prunus persica (L.) Batsch], Sicilia: aspetti fenologici, morfologici e molecolari, Italus Hortus 13 (2) (2006) 118-122. 
[18] Caruso T., La pesca di Bivona, Inf. Agrar. 38 (1982) 21439-21440.

[19] Marchese A., Tobutt K., Caruso T., Molecular characterisation of Sicilian Prunus persica cultivars using microsatellites, J. Hortic. Sci. Biotechnol. 80 (2005) 121-129.

[20] Cusumano G., La pesca di Bivona versol'IGP Riv. Fruttic. Ortofloric. 71 (4) (2009) 82-83.

[21] Montevecchi G., Vasile Simone G., Masino F., Bignami C., Antonelli A., Physical and chemical characterization of Pescabivona, a Sicilian white flesh peach cultivar [Prunus persica (L.) Batsch], Food Res. Int. 45 (2012) 123-131.

[22] Génard M., Bruchou C., Multivariate analysis of within-tree factors accounting for the variation of peach fruit quality, Sci. Hortic. (Amst.) 52 (1992) 37-51.

[23] Anon., Sensory analysis - General guidance for the selection, training and monitoring of assessors - Part 1: Selected assessors, ISO 8586-1, Int. Org. Stand., Geneva, Switz., 1993.

[24] Anon., Sensory analysis - Methodology Method of investigating sensitivity of taste, ISO 3972, Int. Org. Stand., Geneva, Switz., 1991.

[25] Meilgaard M., Civille G.V., Carr B.T., Descriptive analysis in sensory evaluation techniques., 3rd ed., CRC Press Inc., Boca Raton, U.S.A., 1999.

[26] Lea P., Næs T., Rødbotten M., Analysis of variance for sensory data, Wiley \& Sons Ltd. N.Y., U.S.A., 1997.

[27] Anon., Colorimetry: Official recommendation of the international commission on illumination, Bureau Central CIE Publ., CIE No. (E1.31) Paris, France, 1976
[28] O'Mahony M., Sensory evaluation of food: statistical methods and procedures, Marcel Dekker Inc., N.Y., U.S.A., 1986.

[29] Kaiser H.F., The Varimax criterion for analytic rotation in factor analysis, Psychometrika 23 (1958) 187-200.

[30] Minguzzi A., Castellari L., Campani S., Castellari M., Valutazioni analitico-sensoriali della qualità di fruti di pesche e nettarine, in: Sansavini S. (Ed.), Proc. XXIV Natl. "Convegno Peschicolo", Cesena, Italy, 2000, pp. 211-215.

[31] Giacalone G., Peano C., La lacona C., Consumer testing on local and new cultivars of peach in the Roero area, Piedmont, Italy, Acta Hortic. 713 (2006) 457-460.

[32] Infante R., Meneses C., Crisosto C.H., Preconditioning treatment maintains taste characteristic perception of ripe 'September Sun' peach following cold storage, Int. J. Food Sci. Technol. 44 (2009) 1011-1016.

[33] Coultate T.P., Food, The chemistry and its components (4th ed.), Royal Soc. Chem., Camb., U.K., 2002.

[34] Peleg H., Gacon K., Schlich P., Noble A.C., Bitterness and astringency of flavan-3-ol monomers, dimers and trimers, J. Sci. Food Agric. 79 (1999) 1123-1128.

[35] Marwan A.G., Nagel C.W., Identification of the hydroxycinnamic acid derivatives in cranberries, J. Food Sci. 47 (1982) 774-778.

[36] Schlutt B., Moran N., Schieberle P., Hofmann T., Sensory-directed identification of creaminess-enhancing volatiles and semivolatiles in full-fat cream, J. Agric. Food Chem. 55 (2007) 9634-9645. 


\begin{abstract}
Caracterización sensorial de las frutas de cuatro variedades de Pescabivona, melocotones de carne blanca [Prunus persica (L.) Batsch], y su correlación con determinados parámetros físicos y químicos.
\end{abstract}

Resumen - Introducción. Pescabivona es el nombre de una población de melocotoneros autóctonos [Prunus persica (L.) Batsch] del oeste de Sicilia. En un estudio anterior habíamos realizado unos análisis químicos de dicha fruta, mientras que, en el presente documento, hemos realizado la evaluación sensorial del producto. Material y métodos. Se recogieron muestras de cuatro variedades locales de Pescabivona durante toda la temporada de cosecha. Un panel de expertos evaluó los perfiles sensoriales de las frutas recogidas a modo de muestra y los datos se procesaron mediante análisis de varianza y análisis de componentes principales (ACP). Finalmente se midió una correlación entre el análisis sensorial y los datos químicos. Resultados y discusión. Los resultados mostraron una gran calidad de las frutas de las cuatro variedades estudiadas, con algunas diferencias de intensidad aromática y de otros parámetros, y en general con una correlación muy alta del dulzor y el aroma con el sabor. El ACP no permitió separar claramente las diferentes variedades locales, ya que su origen es el mismo. Se verificaron las correlaciones entre el análisis sensorial y los datos de composición química. El sabor se correlacionó con los principales parámetros de madurez, así como con la fermentación de la pulpa. Conclusión. Los datos obtenidos contribuyen a definir un perfil sensorial completo de las frutas para su comparación y el control de su duración de vida. Al igual que con los parámetros químicos verificados anteriormente, la evaluación sensorial reveló una gran similitud de las variedades locales. La concordancia entre la evaluación sensorial y la composición de las frutas hacen del análisis sensorial una preciada herramienta para evaluar la calidad de las variedades locales de melocotones Pescabivona.

Italia / Sicilia / Prunus persica / variedades indigenas / frutas / propiedades organolépticas / análisis de componentes / análisis de la regresión / calidad / aceptabilidad 